
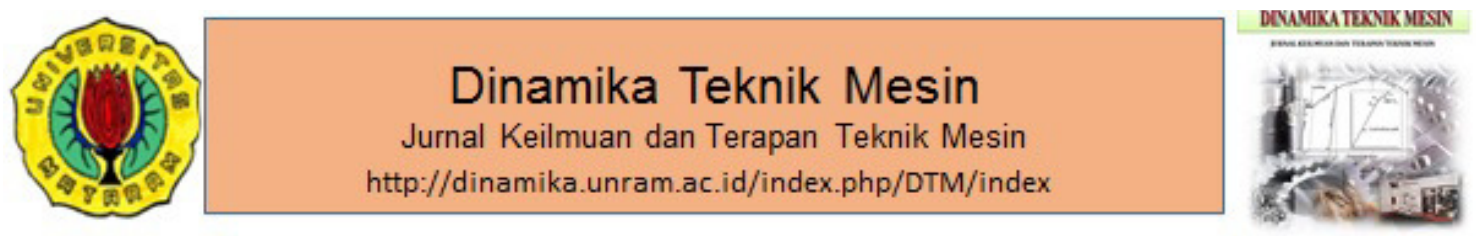

\title{
Analisis pengaruh profil sudu dan jumlah sudu terhadap unjuk kerja turbin angin poros horizontal pada daerah kecepatan angin rendah
}

\section{The analysis of infulence blade profle and blade number for performance of wind turbine blade in the low wind speed area}

\author{
I.K. Wiratama*, I.D.K. Okariawan, I.G.N.K. Yudhiadi, I.M. Mara, A. Juliansah \\ Jurusan Teknik Mesin, Fakultas Teknik, Universitas Mataram, Jl. Majapahit No.62 Mataram NTB, \\ 83125, Indonesia. HP. 07864749700 \\ *Email : kwiratama@tm.frunram.ac.id
}

\section{ARTICLE INFO ABSTRACT}

Article History:

Received 9 December 2018

Accepted 19 December 2019

Available online 1 January 2019

Keywords:

Horizontal axes wind turbine

Blade profile

Blade number

Power

Tip speed ratio
Recently, application of wind energy is very wide in many sectors. As a archipelago country, Indonesia has potential average wind speeds between $2 \mathrm{~m} / \mathrm{s}$ to $6 \mathrm{~m} / \mathrm{s}$ in its most area, and especially in the Nusa Tenggara, the wind speed able to reach above $5 \mathrm{~m} / \mathrm{s}$. This research was conducted to obtain the performance characteristics of horizontal axle wind turbine in wind speed at $7 \mathrm{~m} / \mathrm{s}$ by variation blade profile and number of blades in variation form 3, 4, 5, and 6. The shape of the blade that is used variations of the big taper, half thin small, half tapered and small taper and to generate wind, a moving test methods by using a vehicle was used in this test. The results show that the maximum rotor rotation speed is generated on the shape of a large tapered blade around with an amount of 3 blades around $865.76 \mathrm{rpm}$. Maximum $C_{p R}$ is produced on the shape of a large tapered blade with an amount of 4 blades around 0.48 as a result of TSR is 8.69. For variation shape and number of blade, the best result is on a large tapered blade at number of blades 4 with maximum rotor and torque power around 182.01 $\mathrm{W}$ and 3.25 Nm respectivly .

\section{PENDAHULUAN}

Energi angin merupakan salah satu sumber energi yang dapat diperbaharui (Burton dkk., 2008; Crespo dkk., 1999; Spera, 1994; Robert dan Jochen, 2011). Pemanfaatan energi angin sekarang ini sudah dimanfaatkan untuk berbagai keperluan seperti untuk energi listrik dan juga menjadi energi gerak untuk berbagai keperluan pertanian dan peternakan (Manwell, 2002). Sebagian besar wilayah Indonesia memiliki potensi energi angin sangatlah besar dengan kecepatan angin berkisar antara 2 $\mathrm{m} / \mathrm{s}$ hingga $6 \mathrm{~m} / \mathrm{s}$ sehingga wilayah ini sangat potensial dimanfaatkan potensi energi anginnya untuk menghasilkan energi listrik. Khusus untuk di wilayah Nusa Tenggara kecepatan angin dapat mencapai 
Dinamika Teknik Mesin. Wiratama dkk.: Analisis pengaruh profil sudu dan jumlah sudu terhadap unjuk kerja turbin angin poros horizontal pada daerah kecepatan angin rendah

$>5 \mathrm{~m} / \mathrm{s}$ sehingga memungkinkan untuk pemanfaatan energi angin skala kecil $(10 \mathrm{~kW})$ dan menengah (10-100 kW). Dari kondisi tersebut, dapat diambil kesimpulan bahwa potensi sumber daya energi terbarukan, terutama angin, di Indonesia masih sangat luas. Pemanfaatan energi angin akan dapat mengatasi keterbatasan suply pembangkit listrik yang sudah ada secara menyeluruh dan juga dapat digunakan dalam skala kecil, contohnya untuk sektor perumahan.

Turbin angin, sebagai alat untuk mengkonversikan energi angin menjadi lisrtik, dapat menjadi salah satu jawaban atas masalah krisis energi yang terjadi sekarang ini. Turbin angin diproduksi dengan daya keluaran berkisar antara $600 \mathrm{~kW}$ hingga $1 \mathrm{MW}$, bahkan sudah ada yang mencapai 2,5 MW olehkarena itu teknologi turbin angin haruslah dikembangkan untuk penggunaan yang lebih luas dan lebih mudah didalam penginstalasian dan operasionalnya (Erich, 2006).

Turbin angin skala kecil untuk area pemukiman dirancang untuk mengatasi masalah krisis energi, dimana energy listrik yang dihasilkan dapat memenuhi kebutuhan sehari-hari, tidak menimbulkan suara bising, tidak membebani bangunan lain, dan dari sisi dampaknya pada lingkungan adalah turbin tidak menghasilkan polusi sedikitpun.

Dalam rangka pengembangan turbin angin poros horizontal maka telah dilakukan berbagai penelitian untuk menghasilkan sistem yang mampu bekerja secara optimal. Jureczko dkk. (2005) dan Seki dkk. (1996) menginvestigasi peningkatan daya rata-rata turbin angin dengan mengoptimasi desain sudu untuk mendapatkan sudu yang optimal dengan metode Genetik Algorithm. Untuk meningkatkan aerodinamik performan dari desain sudu maka peningkatan efesiensi sudu dapat dilakukan dengan menggunakan airfoil pada desain sudu yang diterapkan pada rotor turbin angin (Snell, 1998; Snell, 2003; Tangler, 2002). Untuk mendapat koefisien daya yang maksimal maka dapat mengunakan sudu berjumlah banyak dimana tujuannya adalah untuk meningkatkan torsi pada kecepatan angin yang rendah (Seki dkk., 1996).

Dari beberapa penelitian terkait kerja turbin angin, Wiratama (2014) menginvsetigasi terhadap validasi AWTSim yaitu sebuah program analisis untuk menganalisa aerodinamik performan dari rancangan desain sudu dengan analisis Blade Element Momentum Therory (BEMT). Wiratama dkk. (2014) melakukan penelitian terkait performansi sudu turbin angin pada variasi panjang sudu dan variasi panjang chord, pada pengujian ini menggunakan prony breake untuk mendapatkan putaran dan torsi dari rotor turbin angin dan dari pengujian menunjukkan bahwa pada variasi jumlah sudu empat pada panjang chord $55 \mathrm{~mm}$ dihasilkan daya terbesar. Hal yang sama juga dilakukan oleh Sayoga dkk. (2014) dengan melakukan pengujian terhadap rancangan sudu turbin angin 300 watt dengan menggunakan generator untuk menghasilkan listrik. Pada pengujian tersebut divariasikan jumlah sudu pada rotornya. Dari pengujian menunjukkan bahwa pada jumlah sudu lima menghasilkan daya listrik terbesar. Wiratama dkk. (2014) melakukan pengujian yang sama terkait efesiensi turbin angin. Terkait pengaruh density udara terhadap kinerja turbin angin Wiratama dkk. (2016) menginvestigasi faktor - faktor yang mempengaruhi kurva daya rotor dimana dari hasil penelitian menunjukkan bahwa parameter operasional turbin angin mempengaruhi langsung terhadap performan turbin angin pada berbagai variasi kecepatan angin. Mahendra dkk. (2013) melakukan penelitian terhadap pengaruh jumlah sudu terhadap unjuk kerja turbin angin Savonius tipe $L$ dengan salah satu kesimpulannya bahwa unjuk kerja paling tinggi terjadi pada turbin angin jumlah sudu 3 . Pada kecepatan angin $7 \mathrm{~m} / \mathrm{s}$ diperoleh BHP 0.267 Watt dan torsi sebesar $0.00398 \mathrm{Nm}$ serta efisiensi sebesar $10.20 \%$ pada kecepatan $5 \mathrm{~m} / \mathrm{s}$. Hal ini dikarenakan turbin savonius type $L$ sudu 3 mempunyai jarak antara sudu satu dengan lainnya terhadap poros sudu turbin mempunyai kerenggangan yang menjadikan aliran angin mengalir dan menerpa sudu dibelakang poros, Kondisi ini akan meningkatkan gaya momen serta mengurangi gaya hambat negatif pada sudu sehingga aliran turbulensi yang terdapat pada turbin tersebut relatif kecil.

Nurcahyadi dkk. (2014) hasil penelitian menunjukakan bahwa kinerja airfoil tertinggi dengan koefisien angkat sebesar 3,16 dicapai oleh airfoil dengan lokasi ketebalan maksimum pada $40 \%$ panjang kordanya (diukur dari ujung awal) dengan sudut serang $20 \%$ dan kecepatan aliran bebas sebesar $8,9 \mathrm{~m} / \mathrm{s}$.

Sukamto (2012) melakukan penelitian terhadap Karakteristik Turbin Angin Vertical Axis Profil NACA 0018 dengan 3 sudu berbantuan guide vane bertujuan untuk mengetahui pengaruh jumlah blade, pengaruh profil, naca 0018 dan guide vane terhadap besarnya daya dan efisiensi yang di hasilkan. Hasil penelitiannya menunjukkan kecepatan angin $2,86 \mathrm{~m} / \mathrm{s}$ menghasilkan daya dan efisiensi $15,82 \%$, yaitu dari sudut pitch 30 ' berbantu guide vane mampu mengangkat beban sebesar $0,3 \mathrm{~kg}$ setinggi $0,1 \mathrm{~m}$ dengan waktu 4,76 detik dan kecepatan angin $3,43 \mathrm{~m} / \mathrm{s}$ menghasilkan daya dan efisiensi $13,01 \%$, yaitu dari sudut pitch $30^{\circ}$ berbantu guide vane mampu mengangkat beban sebesar $0,3 \mathrm{~kg}$ setinggi $0,1 \mathrm{~m}$ dengan waktu 3,86 detik. 
Dinamika Teknik Mesin. Wiratama dkk.: Analisis pengaruh profil sudu dan jumlah sudu terhadap unjuk kerja turbin angin poros horizontal pada daerah kecepatan angin rendah

Adapun tujuan dari penelitian ini adalah untuk mengetahui pengaruh bentuk profil dan jumlah sudu terhadap unjuk kerja turbin angin dan untuk mengetahui unjuk kerja terbaik dari variasi yang ada dalam mengkonversi energi angin.

\section{METODE PENELITIAN}

Metode yang digunakan pada penelitian ini adalah metode eksperimen. Dimana pengujian prototype sudu pada berbagai profil sudu dan variasi jumlah sudu dilakukan dengan sistem bergerak (Moving Vehicle Based Test Method) dengan menggunakan mobil. Pada penelitian ini pengambilan data dilakukan diluar ruangan engan menggunakan bantuan mobil dan digerakkan untuk mendapatkan kecepatan angin $7 \mathrm{~m} / \mathrm{s}$ dengan $\pm 0,5$ pada variasi jumlah sudu $3,4,5$,dan 6 . Data yang diperoleh merupakan data dari pengamatan secara langsung. Adapun data yang di ambil adalah :

1. Putaran poros turbin sebelum diberikan masa pengereman yang diukur dengan arduino.

2. Putaran poros turbin setelah diberikan masa pengereman yang diukur dengan arduino.

Tahapan dari pengambilan data sebagai berikut :

1. Menempatkan prototype turbin angin diletakkan di atas mobil.

2. Menjalankan mobil hingga mendapatkan kecepatan angin $7 \mathrm{~m} / \mathrm{s}$ dan menjaga kecepatan mobil pada $25,2 \mathrm{~km} / \mathrm{jam}$.

3. Tunggu sampai putaran rotor turbin stabil.

4. Setelah putaran rotor stabil, pengambilan data putaran rotor tanpa pengereman dilakukan dengan membaca putaran poros menggunakan arduino.

5. Selanjutnya poros di rem dengan mengencangkan sabuk pengereman. Setelah pengereman pada poros dilakukan maka poros akan berputar lebih pelan dari putaran sebelum pengereman, ketika dilakukan pengereman daya, torsi dan putaran setelah pengeran juga ikut tercatat yang diolah menggunakan program arduino dan ditampilkan di Labveiw.

Dengan cara yang sama dari langkah 1 sampai 6 , pengambilan data untuk putaran sebelum pengereman dan sesudah pengereman pada bentuk dan variasi sudu yang berbeda .

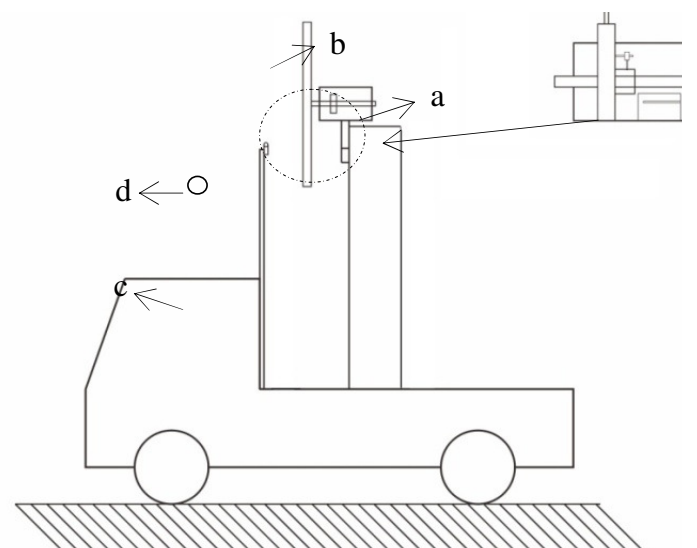

Gambar 1. Skematik pengujian sistem bergerak : a.) Prony break torsi meter dengan arduinologing, b.) Sudu turbin, c. ) tiang kayu, d.) anenometer

Skema alat penelitian yang digunakan yaitu mobil, meteran, multimeter, anemometer ,pronybrake torsi meter dengan arduino loging, mur dan baut, besi siku, plat besi, besi poros.

Variabel terikat pada penelitian ini adalah daya rotor, $C_{P R}$, putaran ( rpm ), tip speed ratio (TSR). Variable bebas dalam penelitian ini yaitu profil tirus dan setengah tirus, bentuk kecil dan besar, Jumlah sudu yang digunakan adalah 3, 4, 5 dan 6 sudu.

\section{HASIL DAN PEMBAHASAN}

Telah dilakukan pengujian putaran rotor untuk mengetahui pengaruh jumlah sudu dan profil sudu terhadap putaran yang dihasilkan oleh turbin angin poros horizontal dengan menggunakan kecepatan angin $7 \mathrm{~m} / \mathrm{s}$. Adapun hasil percobaan berupa besarnya putaran rotor, daya rotor, torsi, koefesien daya, dan tip speed ratio dapat dilihat masing-masing pada tabel 1, tabel 2, tabel 3 , tabel 4 dan tabel 5. 
Dinamika Teknik Mesin. Wiratama dkk.: Analisis pengaruh profil sudu dan jumlah sudu terhadap unjuk kerja turbin angin poros horizontal pada daerah kecepatan angin rendah

Gambar 2 menunjukkan bahwa perbedaan jumlah sudu menyebabkan terjadinya perbedaan besarnya putaran rotor pada setiap profil sudu. Untuk rotor dengan jumlah sudu tiga maka putaran terbesar terjadi pada sudu tirus profil besar saat ditingkatkan jumlah sudunya maka terjadi penurunan putaran yang cukup signifikan baik untuk sudu tirus besar maupun sudu setengah tirus besar . Sebaliknya terjadi peningkatan putaran ketika jumlah sudu ditingkatkan untuk sudu tirus profil kecil. Terlihat pula pada tabel 1 untuk jumlah sudu tiga dengan bentuk sudu tirus besar dan Setengah tirus besar menghasilkan putaran rotor maksimal yaitu masing-masing sebesar 865,76 dan 803,67 rpm, jumlah sudu empat dengan bentuk setengah tirus kecil yaitu sebesar 701,37 rpm, sedangkan pada bentuk tirus kecil dengan jumlah sudu enam dengan putaran yang dihasilkan 680,77 rpm.

Tabel 1. Data putaran rotor turbin angin horizontal sebelum pengereman untuk setiap profil sudu.

\begin{tabular}{|c|c|c|c|c|c|}
\hline \multirow[b]{2}{*}{ Jumlah sudu } & \multicolumn{5}{|l|}{ Profil sudu } \\
\hline & Tirus besar & Setengah tirus kecil & Tirus kecil & $\begin{array}{l}\text { Setengah } \\
\text { besar }\end{array}$ & tirus \\
\hline 3 & 865,76 & 470,74 & 145,31 & 803,67 & \\
\hline 4 & 755,08 & 701,37 & 204,44 & 503,31 & \\
\hline 5 & 577,92 & 658,1 & 251,99 & 440,36 & \\
\hline 6 & 567,91 & 252,41 & 680,77 & 573,28 & \\
\hline
\end{tabular}

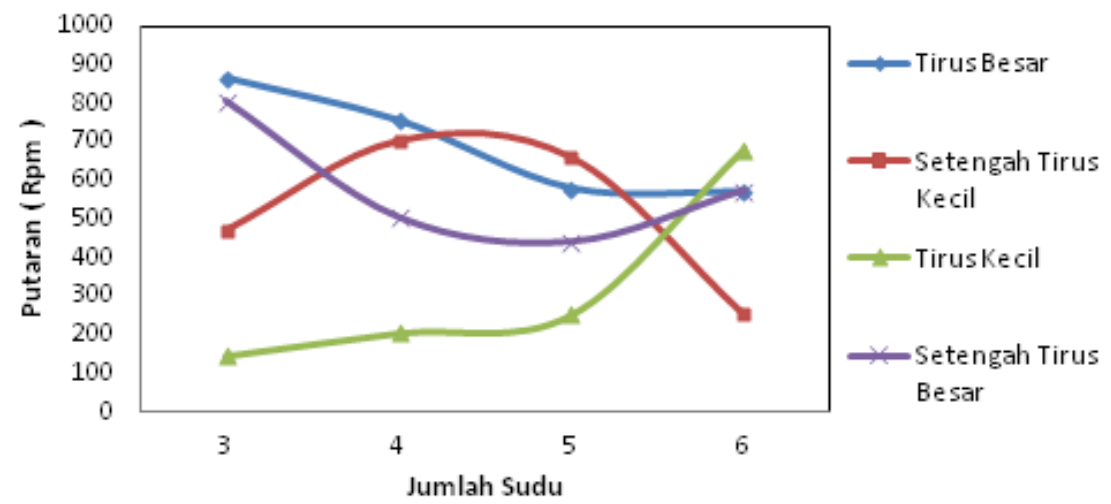

Gambar 2.Hubungan profil sudu danjumlah sudu terhadap putaran rotor pada kecepatan angin $7 \mathrm{~m} / \mathrm{s}$.

Tabel 2. Data daya rotor turbin angin horizontal untuk setiap profil sudu.

\begin{tabular}{lllll}
\hline \multirow{2}{*}{ Jumlah sudu } & \multicolumn{4}{l}{ Daya rotor (watt) } \\
\cline { 2 - 5 } & Tirus besar & Setengah tirus kecil & Tirus kecil & Setengah tirus besar \\
\hline 3 & 163,4 & 0 & 6,74 & 133,25 \\
4 & 182,01 & 26,38 & 14,47 & 78,14 \\
5 & 128,74 & 39,33 & 27,44 & 103,25 \\
6 & 139,39 & 0 & 84,17 & 96,95 \\
\hline
\end{tabular}


Dinamika Teknik Mesin. Wiratama dkk.: Analisis pengaruh profil sudu dan jumlah sudu terhadap unjuk kerja turbin angin poros horizontal pada daerah kecepatan angin rendah

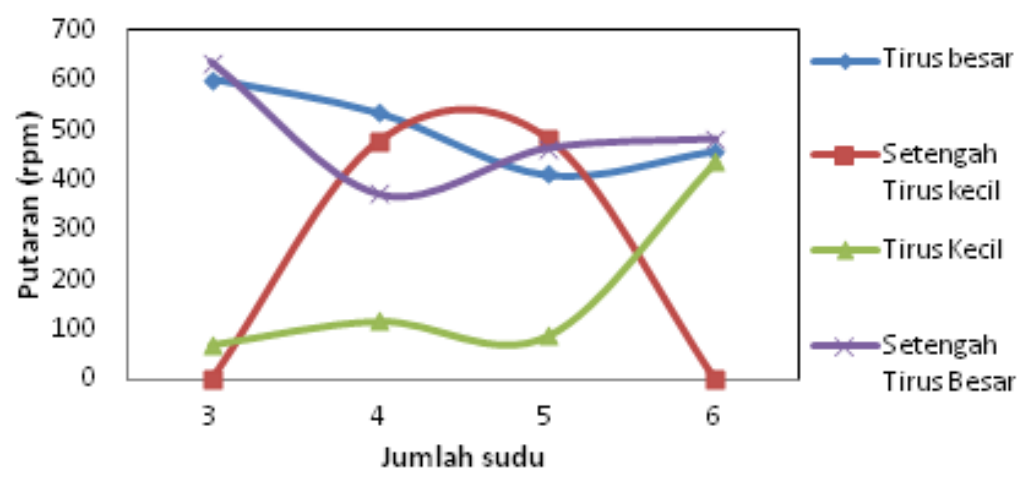

Gambar 3. Hubungan profil sudu dan jumlah sudu terhadap putaran rotor setelah pengereman pada kecepatan angin $7 \mathrm{~m} / \mathrm{s}$.

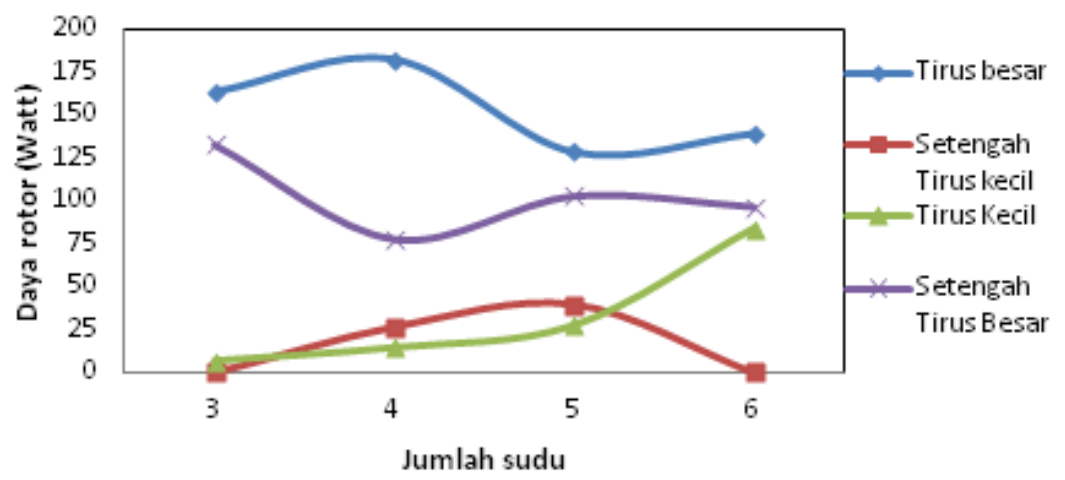

Gambar 4. Hubungan profil sudu dan jumlah sudu terhadap daya rotor pada kecepatan angin $7 \mathrm{~m} / \mathrm{s}$.

Tabel 3. Data torsi turbin angin horizontal untuk setiap profil sudu.

\begin{tabular}{llllll}
\hline \multirow{2}{*}{ Jumlah sudu } & Torsi $(\mathrm{Nm})$ & & & \\
\cline { 2 - 5 } & Tirus besar & Setengah tirus kecil & Tirus kecil & $\begin{array}{l}\text { Setengah } \\
\text { besar }\end{array}$ & tirus \\
\hline 3 & 2,59 & 0 & 0,9 & 2 \\
4 & 3,25 & 0,53 & 1,18 & 2 \\
5 & 2,99 & 0,78 & 2,95 & 2,19 \\
6 & 2,9 & 0 & 1,84 & 1,91 & \\
\hline
\end{tabular}

Berdasarkan gambar 3 dan gambar 4 menunjukkan bahwa rotor terjadi trend yang sama seperti gambar 2. Dari gamabr 3 dan gamabr 4 menunjukkan bahwa sudu dengan profil tirus besar untuk jumlah sudu tiga menghasilkan daya rotor sebesar 163,40 W pada putaran 602,69 rpm dan mengalami peningkatan daya pada sudu 4 sebesar $182,01 \mathrm{~W}$ dengan putaran $534,97 \mathrm{rpm}$, tetapi pada bentuk profil tirus besar sudu 5 mengalami penurunan daya dan putaran yang dihasilkan sebesar 128,74 W pada 412,26 rpm. Akan tetapi dengan penambahan sudu menjadi 6 putaran dapat ditingkatkan lagi sehingga daya yang dihasilkan pun meningkat, yang mana daya yang didapatkan sebesar 139,39 W pada 459,59 rpm. Untuk operasional turbin angin pada kecepatan rendah dan sedang maka pulihan jumlah tiga sudu menjadi pilihan yang terbaik dalam menghasilkan daya untuk kebutuhan energi listrik dibandingkan dengan profil bentuk sudu lainnya. Pada rotor turbin angin dengan profil sudu setengah tirus besar, daya rotor yang dihasilkan pada jumlah sudu tiga merupakan daya rotor tertinggi pada jenis ini yaitu $133,25 \mathrm{~W}$ pada $636,42 \mathrm{rpm}$. Tetapi dengan penambahan jumlah sudu menjadi empat maka terjadi penuruan daya rotor yang dihasilkan Berbeda dengan tubin 
Dinamika Teknik Mesin. Wiratama dkk.: Analisis pengaruh profil sudu dan jumlah sudu terhadap unjuk kerja turbin angin poros horizontal pada daerah kecepatan angin rendah

angin yang menggunakan profil sudu tirus kecil hanya menghasilkan daya sebesar $6,74 \mathrm{~W}$ dengan rpm 71,83 pada jumlah sudu tiga. Seiring dengan penambahan jumlah sudu yang digunakan, daya yang dihasilkan pun meningkat sebesar 14,47 W untuk sudu empat dan 27,44 W untuk sudu lima , tetapi putaran pada sudu lima lebih rendah dari pada sudu empat yaitu $89,21 \mathrm{rpm}$, sedangkan sudu empat yaitu 118,92 rpm. Sedangkan pada sudu enam merupakan daya terbesar yang dihasilkan pada profil sudu tirus kecil dengan daya sebesar 84,17 watt pada putaran 437,96 rpm. Untuk profil sudu setengah tirus kecil maka jumlah sudu tiga dan enam sama sekali tidak dapat menghasilkan daya dikarenakan putaran yang dihasilkan sangatlah rendah sehingga ketika dilakukan pengereman pada rotor turbin berhenti berputar. Akan tetapi pada sudu empat dayanya sebesar 26,38 W pada 477,98 rpm. Daya kembali mengalami peningkatan ketika jumlah sudu ditambah dengan daya yang dihasilkan sebesar 39,33 W pada 482,22 rpm yang merupakan daya tertinggi pada profil sudu setengah tirus kecil.

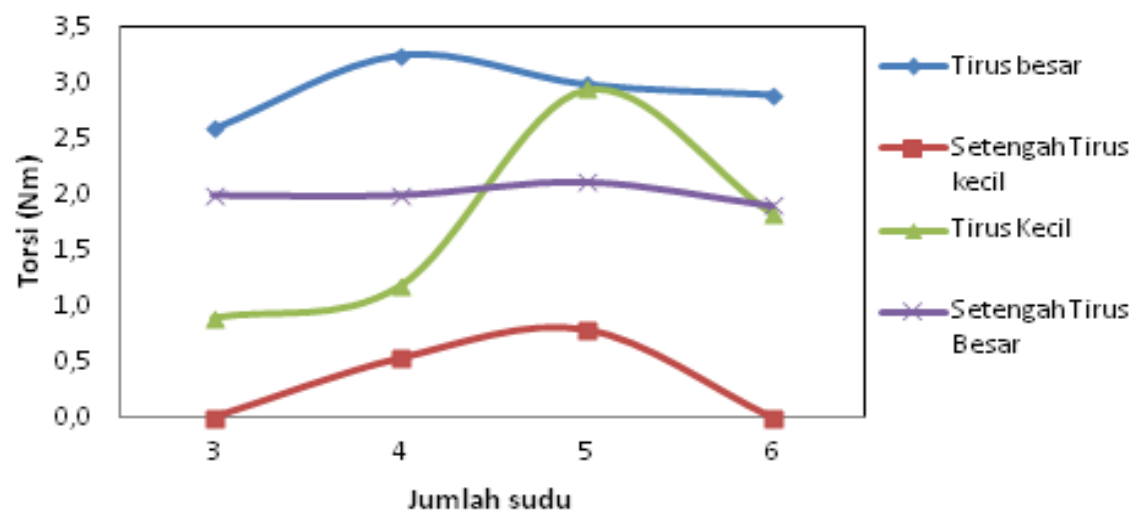

Gambar 5. Hubungan profil sudu dan jumlah sudu terhadap torsi yang dihasilkan pada kecepatan angin $7 \mathrm{~m} / \mathrm{s}$.

Tabel 4. Data $C p_{\mathrm{R}}$ turbin angin horizontal untuk setiap bentuk profil sudu.

\begin{tabular}{lllll}
\hline \multirow{2}{*}{ Jumlah sudu } & $C p_{\mathrm{R}}$ & & \\
\cline { 2 - 5 } & Tirus besar & Setengah tirus kecil & Tirus kecil & Setengah tirus besar \\
\hline 3 & 0,43 & 0 & 0,02 & 0,35 \\
4 & 0,48 & 0,07 & 0,04 & 0,2 \\
5 & 0,34 & 0,1 & 0,07 & 0,27 \\
6 & 0,36 & 0 & 0,22 & 0,25 \\
\hline
\end{tabular}

Dari gambar 5 untuk uji torsi pada berbagai bentuk sudu dan jumlah sudu menunjukkan bahwa sudu dengan profil tirus besar menghasilkan torsi terbesar untuk semua variasi jumlah sudu. Dari gambar 5 untuk sudu tirus besar pada jumlah sudu tiga dihasilkan torsi sebesar 2,59 Nm kemudian terjadi peningkatan torsi yang dihasilkan ketika jumlah sudu ditingkatkan yaitu pada jumlah sudu empat mengalami peningkatan torsi yang dihasilkan menjadi $3,25 \mathrm{Nm}$, tetapi mengalami penurunan ketika penambahan sudu lima dan enam. Pada turbin angin yang mengunakan profil sudu setengah tirus besar, torsi yang dihasilkan pada setiap jumlah sudu pada bentuk profil ini dapat dikatakan bahwa perbedaan torsi yang dihasilkan tidak terlalu jauh pada setiap jumlah sudu yang berkisar \pm 2 $\mathrm{Nm}$. Pada turbin angin yang dengan profil sudu tirus kecil mendapatkan $0,90 \mathrm{Nm}$ pada jumlah sudu tiga dan penambahan jumlah sudu mengakibatkan peningkatan torsi hingga 2,95 Nm dengan jumlah sudu lima, akan tetapi pada sudu enam mengalami penurunan drastis menjadi 1,84 $\mathrm{Nm}$. Sedangkan turbin angin yang menggunkan profil sudu setengah tirus kecil pada sudu 3 tidak menghasilkan torsi karena putaran rotor rendah, pada sudu 4 menghasilkan torsi sebesar $0,53 \mathrm{Nm}$, kembali meningkat menjadi $0,78 \mathrm{Nm}$ pada sudu 5 dan pada sudu 6 tidak menghasilkan torsi. 
Dinamika Teknik Mesin. Wiratama dkk.: Analisis pengaruh profil sudu dan jumlah sudu terhadap unjuk kerja turbin angin poros horizontal pada daerah kecepatan angin rendah

Gambar 6 pada turbin dengan profil sudu tirus besar menghasilkan $C p_{\mathrm{R}}$ maksimal pada jumlah sudu empat sebesar 0,4751 , untuk profil sudu setengah tirus besar menghasilkan $C p_{\mathrm{R}}$ maksimal pada jumlah sudu tiga sebesar 0,4378. Sedangkan pada profil sudu tirus kecil dan setengah tirus kecil ang menghasilkan $C p_{R}$ maksimal pada jumlah sudu enam dan lima masing-masing sebesar 0,2197 dan 0,1027 .

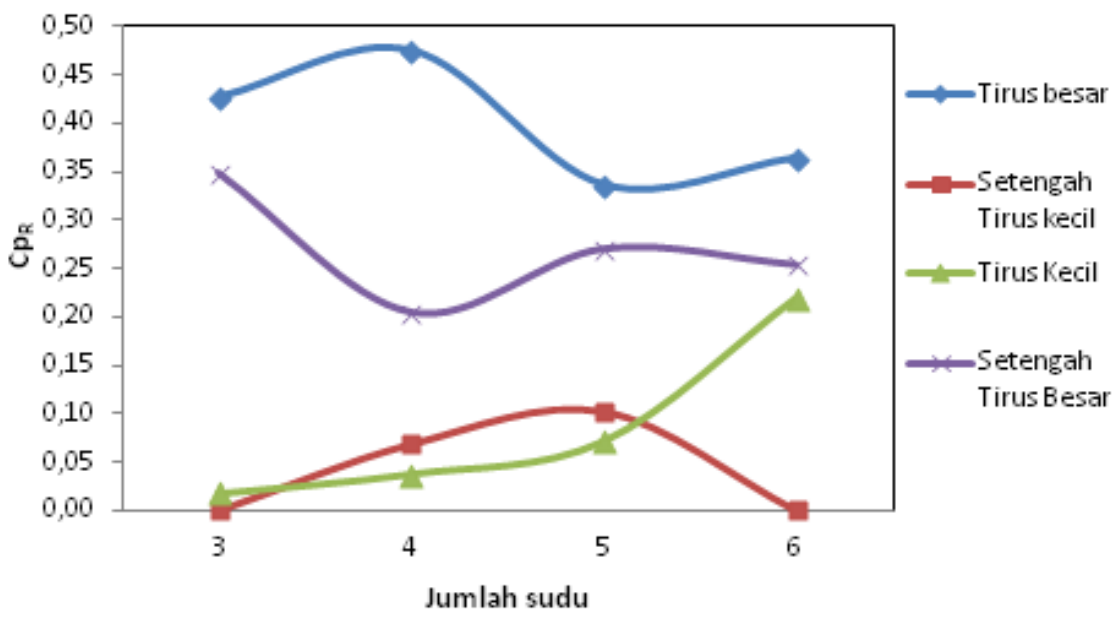

Gambar 6. Hubungan profil sudu dan jumlah sudu terhadap $C p_{\mathrm{R}}$ yang dihasilkan pada kecepatan angin $7 \mathrm{~m} / \mathrm{s}$.

Tabel 5. Data TSR turbin angin horizontal untuk setiap bentuk profil sudu.

\begin{tabular}{lllll}
\hline \multirow{2}{*}{ Jumlah sudu } & TSR & & \\
\cline { 2 - 5 } & Tirus besar & Setengah tirus kecil & Tirus kecil & Setengah tirus besar \\
\hline 3 & 9,97 & 5,42 & 1,67 & 9,25 \\
4 & 8,69 & 8,08 & 2,35 & 5,79 \\
5 & 6,65 & 7,58 & 2,9 & 5,07 \\
6 & 6,54 & 2,91 & 7,84 & 6,60 \\
\hline
\end{tabular}

Gambar 7 Bentuk profil sudu tirus besar menghasilkan TSR maksimum 9,97 pada sudu tiga dengan putaran $865,76 \mathrm{rpm}$. Dan dengan menggunakan profil sudu setengah tirus besar memiliki nilai TSR sebesar 9,25 dengan putaran 803,67 rpm. Sedangkan untuk profil sudu tirus kecil dan setengah tirus kecil memiliki nilai TSR pada sudu enam dan empat masing-masing sebesar 7,84 dan 8,08 dengan putaran 680,77 rpm dan 701,37 rpm. Sehingga nilai TSR maksimal untuk profil sudu didapatkan pada jumlah sudu dimana poros mengalami putaran tertinggi. Berdasarkan gamabr 7 maka untuk pemilihan bentuk sudu maka sudu tirus besar menjadi pilihan terbaik ketika dipalikasikan untuk daerah berkecepatan angin rendah dan sedang. 
Dinamika Teknik Mesin. Wiratama dkk.: Analisis pengaruh profil sudu dan jumlah sudu terhadap unjuk kerja turbin angin poros horizontal pada daerah kecepatan angin rendah

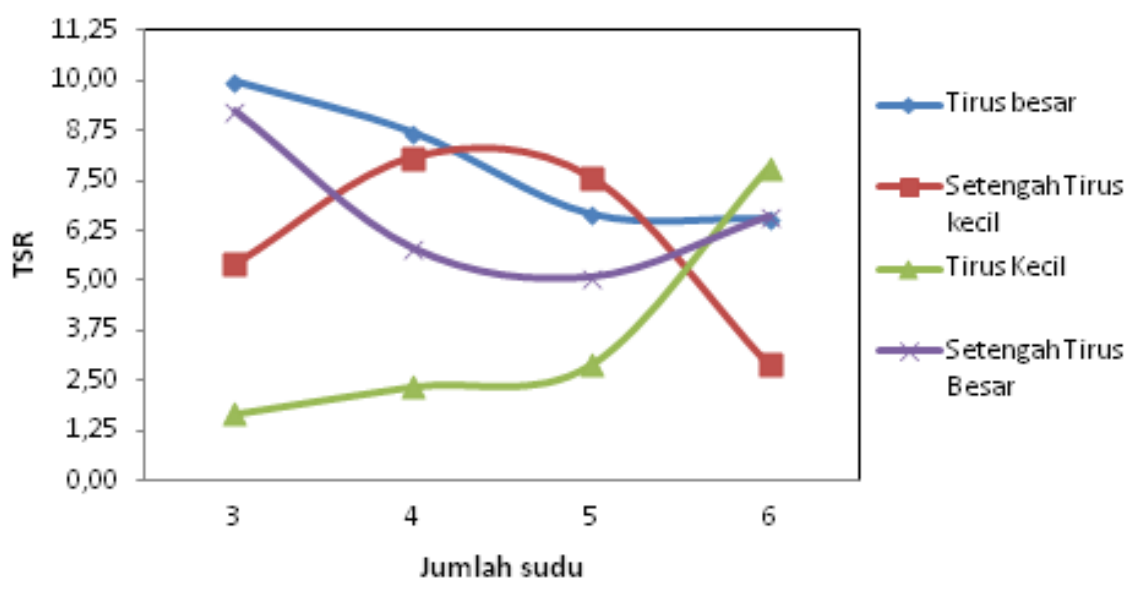

Gambar 7. Hubungan profil sudu dan jumlah sudu terhadap TSR yang dihasilkan pada kecepatan angin $7 \mathrm{~m} / \mathrm{s}$.

\section{KESIMPULAN}

Dari hasil penelitian yang telah dilakukan, dapat diambil suatu kesimpulan sebagai berikut :

1. Berdasarkan anova dua arah menunjukkan bahwa perbedaan profil sudu dan jumlah sudu memberikan pengaruh terhadap unjuk kerja yang dihasilkan turbin angin poros horizontal sehingga untuk profil sudu tirus besar dengan jumlah tiga sudu dapat diaplikasikan untuk dioperasikan didaerah berkecepatan angin rendah dan sedang..

2. Unjuk kerja terbaik dihasilkan oleh profil sudu tirus besar dengan jumlah sudu empat yang menghasilkan daya sebesar 182,01 W pada 534,97 rpm dan torsi sebesar $3,25 \mathrm{Nm}$ juga pada $534,96 \mathrm{rpm}$.

3. Desain untuk profil sudu dan jumlah sudu terbaik adalah tirus besar dengan sudu empat, sudu turbin tersebut telah mampu mencapai kinerja optimum pada kecepatan angin $7 \mathrm{~m} / \mathrm{s}$, dikarenakan turbin angin dengan sudu empat memiliki nilai $C p_{R}$ berkisar antara 0,4 sampai dengan 0,5 dan TSR berkisar antara 5 sampai dengan 10 .

\section{UCAPAN TERIMAKASIH}

Penulis pada kesempatan ini mengucakan terimakasih kepada semua pihak yang membantu baik berupa materi maupun pikiran sehingga penelitian dan paper ini dapat terselesaikan. Yang kedua penulis mengucapkan terimakasih kepada Kemenristek Dikti atas bantuan dana penelitian melalui program penelitian Insinas tahun 2017. Yang ke tiga penulis mengapresiasi Jurusan Teknik Mesin atas fasilitas yang dipergunakan dalam penelitian ini.

\section{DAFTAR PUSTAKA}

Burton T., Sharpe D., Jenkins N. , Bossanyi E., 2008, Wind energy handbook, John Wiley \& Son Inc.

Crespo A., Hernández J., Frandsen S., 1999, Survey of modelling methods for wind turbine wakes and wind farms, Wind Energy, 2, 1-24.

Erich H., 2006, Wind turbines fundamentals, technologies, application, economics, Edisi Kedua, Germany, Springer.

Jureczko M., Palwak M, Męźyk A., 2005, Optimisation of wind turbine blade, Materials Processing Technology, 167, 463-471.

Mahendra B., Rudy S., Djoko S., 2013, Pengaruh jumlah sudu terhadap unjuk kerja turbin angin savonius type L, Jurusan Teknik Mesin Fakultas Teknik, Universitas Brawijaya, Malang.

Manwell J.F., 2002, Wind energy explained theory, dasign and Application, Amherst: John Wiley and Sons, Ltd.

Nurcahyadi, Teddy, Sudarja, 2014, Pengaruh lokasi ketebalan maksimum airfoil simetris terhadap koefisien angkat aerodinamisnya, Teknik Mesin Fakultas Teknik, Universitas Muhammadiyah Yogyakarta.

Robert G., Jochen T., 2011, Wind power plants fundamentals, design, construction and operation,Springer. 
Dinamika Teknik Mesin. Wiratama dkk.: Analisis pengaruh profil sudu dan jumlah sudu terhadap unjuk kerja turbin angin poros horizontal pada daerah kecepatan angin rendah

Sayoga I.M.A., Wiratama I.K., Catur A.D., 2014, Pengaruh variasi jumlah blade terhadap aerdinamik performan pada rancangan kincir angin 300 watt, Jurnal Dinamika Teknik Mesin, 4(2), 103-109.

Seki K., Shimizu Y., Zhu K., 1996, A design strategy for the improvement of an existing 300kW WTGs rotor blade, Renewable Energy, 9, 858-86.

Snel H., 1998, Review of the present status of rotor aerodynamics, Wind Energy, 1, 46-69.

Snel H., 2003, Review of aerodynamics for wind turbines, Wind Energy, 6, 203-211.

Spera D.A., 1994, Wind turbine technology, fundamental concepts of wind turbine engineering, American Society of Mechanical Engineers.

Sukamto, 2012, Karakteristik turbin angin vertical axis profil NACA 0018 dengan 3 blade berbantuan guide vane, Teknik Mesin, Fakultas Teknik. Universitas Negeri Surabaya.

Tangler J.L., 2002, The nebulous art of using wind tunnel aerofoil data for predicting rotor performance, Wind Energy, 5,245-257.

Wiratama I.K., Mara I.M., Prina L.E.F., 2014 ,Pengaruh jumlah blade dan variasi panjang chord terhadap performansi turbin angin sumbu horizontal (TASH), Jurnal Dinamika Teknik Mesin, 4(2), 110-116.

Wiratama I.K., Mara I.M., Mulyanto A., Harianhady M., 2014, Pengaruh variasi jumlah blade turbin angin terhadap output daya listrik, Jurnal Dinamika Teknik Mesin, 4(1), 25-29.

Wiratama I.K, 2014, Validation of AWTSim as aerodynamic analysis for design wind turbine blade, Journal Applied Mechanics and Materials, 493, 105-110.

Wiratama I.K., Mara I.M., Nuarsa I.M., 2016, Investigation of factors affecting power curve wind turbine blade, Journal of Engineering and Applied Sciences, 11(4), 2759-2762. 